\title{
Single-Nuclear DNA Instability Analyses by Means of Single-Cell Pulsed- Field Gel Electrophoresis - Technical Problems of the Comet Assay and Their Solutions for Quantitative Measurements
}

\author{
Satoru Kaneko ${ }^{1 *}$, Joji Yoshida1, Hiromichi Ishikawa² and Kiyoshi Takamatsu \\ ${ }^{1}$ Reproduction Center, Gynecology, Ichikawa General Hospital, Tokyo Dental College, 5-11-13 Sugano, Ichikawa, Chiba, Japan \\ ${ }^{2}$ Reproduction Center, Urology, Ichikawa General Hospital, Tokyo Dental College, 5-11-13 Sugano, Ichikawa, Chiba, Japan
}

\begin{abstract}
Throughout the past decade, the neutral and alkaline comet assays, which lyses cells with high salt in the absence of proteolysis, have been the most widely used methods to observe single- or double-strand breaks (SSB, DSB) in a single nucleus. These methods evaluate the degree of DNA damage based on the amount of granular fragments discharged from the origin, the so-called "comet tail," but not of long chain DNA fibers. Meanwhile, a novel, single-cell pulsed-field gel electrophoresis (SCPFGE) method, which digested cells with trypsin, observed a different course of DNA fragmentation: first, a few large fibrous fragments were derived from a bundle of long chain fibers, then the cleavages were advanced until finally almost all the DNA was shredded to granular fragments. Some nuclear DNA binding components were tolerant for high salt and high alkalinity, but were degraded by trypsin digestion. A lack of trypsin digestion causes false negative results in both SCPFGE and comet assays. Also, most DNA fibers were still fixed with components, and the comet tail did not reflect a total amount of granular fragments, but rather those that released components. Repair of DSB is intrinsically difficult as compared to other DNA lesions, and the critical threshold is extremely low.DNA fibers that have already been shredded to numerous granular fragments may be irreparable as a result.
\end{abstract}

Although $100-300 \mathrm{mmol} / \mathrm{L} \mathrm{NaOH}$ was commonly used in the alkaline comet assay, the naked DNA fibers persisted in $10 \mathrm{mmol} / \mathrm{L} \mathrm{NaOH}$ after trypsin digestion, but were shredded to granular fragments by $30 \mathrm{mmol} / \mathrm{L}$. Neogenesis of the granular fragments by high $\mathrm{pH}$ did not clarify the mechanism of such a result; that is, it was unknown whether it was due to dissociation of hydrogen bonds, strand breaks through alkaline labile sites, artifactual DSB, or a combination of actions. Optimum conditions for the comet assay need to be defined to achieve quantitative measurements.

DNA instability analyses by means SCPFGE is likely to serve as a fundamental step in single-cell genomics to determine the competence of the cell population provided for DNA amplification methods and is likely to play an important role in ensuring the safety of clinical regenerative medicine.

Keywords: DNA fragmentation; The comet assay; Alkaline; Human sperm; Single-strand breaks; Double-strand breaks; Single-cell pulsedfield electrophoresis; Trypsin

\section{Introduction}

Recent advances in tissue engineering have focused on the clinical applications of cultured cells in regenerative medicine. Primary and stem cells retrieved from various human tissues often have modulated cellular properties by means of various gene engineering technologies. During in vitro processing and subculture in artificial circumstances, inter-cellular differences, such as in gene expression and DNA sequence may exist among the proliferating cell population. The precise control of culture environment [1] and the comprehensive validation of the cultured cells are essential to ensure clinical reliability. The uses of DNA for diagnoses, including parentage diagnoses, are premised on the principle that the cell population in one body has approximately the same DNA sequence, whereas those between individuals show polymorphism. Conventional genome sequencing and transcriptome sequencing methods require DNA/RNA extracted from a population of cells. Hence, genetic variations unique to individual cells are often lost in a population average and de novo mutation in a cell is often concealed in the bulk signal. Analyses of single cells are essential when dissecting the genetic makeup of heterogeneous tissues to understand the causes of disease and phenotypes, and to perform basic genome stability research. Assessment of homogeneity in cell populations is also important for clinical regenerative medicine to ensure the competence of the cells provided for transplantation. Single-cell genomics using single-cell DNA or RNA amplification methods [2-6] need sufficient material to allow sequencing. However, the interpretation of singlecell sequencing data is complicated by various amplification biases introduced in the cell's DNA or RNA sample and requires dedicated approaches to sift these amplification artifacts from true genetic changes.

Fluorescence in situ hybridization (FISH) is the most famous cytogenetic technique to detect and localize the presence or absence of specific DNA sequences on chromosomes in a single cell [7]. Cells are disseminated on a solid phase and the signals are visualized microscopically. Prior to analyses of single cells by means of highly advanced technologies, e.g. high-throughput single cell whole-genome

*Corresponding author: Satoru Kaneko, Reproduction Center, Gynecology, Ichikawa General Hospital, Tokyo Dental College, 5-11-13 Sugano, Ichikawa, Chiba 272-8513, Japan, E-mail: kaneko@tdc.ac.jp

Received March 26, 2013; Accepted June 17, 2013; Published June 19, 2013

Citation: Kaneko S, Yoshida J, Ishikawa H, Takamatsu K (2013) Single-Nuclear DNA Instability Analyses by Means of Single-Cell Pulsed-Field Gel Electrophoresis - Technical Problems of the Comet Assay and Their Solutions for Quantitative Measurements. J Mol Biomark Diagn S5: 005. doi:10.4172/2155-9929.S5-005

Copyright: ( 2013 Kaneko S, et al. This is an open-access article distributed under the terms of the Creative Commons Attribution License, which permits unrestricted use, distribution, and reproduction in any medium, provided the original author and source are credited 
Citation: Kaneko S, Yoshida J, Ishikawa H, Takamatsu K (2013) Single-Nuclear DNA Instability Analyses by Means of Single-Cell Pulsed-Field Gel Electrophoresis - Technical Problems of the Comet Assay and Their Solutions for Quantitative Measurements. J Mol Biomark Diagn S5: 005. doi:10.4172/2155-9929.S5-005

amplification and ultra-high sensitive DNA sequencing [8], elementary but indispensable measurements for detection of nonspecific sequential damage of DNA, such as single- or double-strand breaks (SSB, DSB), need to be performed.

In the apoptotic process, the activation of $\mathrm{Ca} / \mathrm{Mg}$-dependent endonucleases cleaves DNA strands in a specific manner into nucleosomal units of $\sim 185$ base pairs [9]. This process can be triggered by extracellular agents such as hormones, cytokines, and numerous chemical or viral agents, which are often employed for modulation of cell properties and subsequent subculture $[10,11]$. SSB is one of the most frequent DNA lesions, and they are produced daily in nuclei during DNA repair processes such as base excision repair (BER) [12]. It is a primary response pathway for the repair of deleterious DNA lesions including non-bulky DNA adducts, apurinic/apyrimidinic (AP) sites $[13,14]$, and SSB. From a chemical point of view, the abasic site is an alkaline-labile residue that leads to strand breaks through beta- and delta- elimination [15]. If unrepaired, these lesions threaten genetic integrity through their potential conversion to lethal DSB during DNA replication.

Throughout the past decade, the comet assay has been the most widely used method to observe SSB and DSB in a single nucleus due to its ease and relative cost effectiveness [16-26]. The guidelines, principles and techniques for the comet assay are summarized as follows $[16,17,21,24,25]$. Cells are embedded in agarose and lysed with detergent under high salt conditions. This process removes protamine and histones, allowing the nucleus to form a nucleoid-like structure containing supercoiled loops of DNA. Alkaline $\mathrm{pH}$ conditions result in unwinding of double-stranded DNA $[17,21,26]$, and subsequent electrophoresis results in the migration of broken strands towards the anode, which forms a comet tail when observed under fluorescent microscopy. The amount of DNA in the head and tail is reflected by its fluorescent intensity. The relative fluorescence in the tail compared with its head serves as a measure of the degree of DNA damage.

We have reported a novel, single-cell pulsed-field gel electrophoresis (SCPFGE) to detect the early stage of DNA fragmentation in a single nucleus [27]. In this method, cells were initially digested with trypsin. The ensuing electrophoretic profiles, the detection sensitivity of the DNA fragments at neutral $\mathrm{pH}$, and the tolerance for high alkalinity were entirely different from those determined using the neutral and alkaline comet assays. In this review, we would like to discuss the technical differences between the comet assay and SCPFGE, discuss two major problems in the comet assay, and offer potential solutions to establish a standard protocol for quantitative measurements.

\section{Setting Detection Sensitivity-A Critical Threshold Number for Double Strand Breaks in Human Sperm}

Our previous report [27] used human sperm as research material, and there were critical situations for concern in terms of maintaining DNA integrity. Male germ cells are susceptible to the accumulation of DNA lesions because their DNA repair capacity declines during late spermatogenesis [28]. In contrast, the mammalian oocyte is capable of repairing DNA lesions throughout oogenes is [29-31], and DNA lesions have to be repaired in the embryo during the first cell cycle [32]. To date, the repair mechanisms for critical DNA damage in somatic cells have been studied in detail, whereas the capacity and accuracy of repair in human embryos as well as factors disrupting these processes [1,33-35] have beenpoorly understood. Incomplete DNA repair is promutagenic and responsible for sperm-derived congenital anomalies in newborns.
Fertilization through intra-cytoplasmic sperm injection (ICSI) now accounts for more than half of clinical infertile therapies by the aid of assisted reproductive technology (ART) worldwide. Selection of a sperm for the injection is based on light microscopic observations of motility and gross morphology at a low magnification. There is a concern about higher malformations resulting from ICSI approaches as compared to natural births [36-38]. Thus, there is a possibility of iatrogenic transmission of genetic abnormalities to the offspring. The validation of DNA in human sperm represents essentially important diagnostic and prognostic measures as compared with other regenerative medicine using somatic cells. The critical threshold of DSB in a sperm may be null or extremely low to complete embryogenesis and subsequent fetal development, whereas the repair of DSB is intrinsically difficult as compared to other DNA lesions $[39,40]$. The comet assay evaluates the level of DNA damage by the amount of granular fragments migrated from the origin, the so-called "comet tail", and DNA fibers that have already been shredded to numerous granular fragments may be irreparable. When considering the genetic influences of sperm that can survive after repair, the critical situation may be the early stage of strand breaks where a few large fibrous fragments are derived from whole DNA. Thus, we have set the detection sensitivity of SCPFGE to separate large fibrous fragments derived from a single nucleus [27].

\section{Principles and Differences of Macro- and Micro- Agarose Gel Electrophoreses}

Submarine agarose gel electrophoresis is one of the most common types of macro-electrophoresis [41,42] used to determine the size of DNA fragments in the range of 500 to 30,000 base pairs. DNA samples extracted from a cellular population are aligned at the origin and migrate several or more centimeters. Agarose forms thermoplastic gels consisting of thick bundles of polysaccharide chains cross-linked by hydrogen bonds, with large pores. The amount of negative charge by $\mathrm{PO}_{4}$ is proportional to the size of DNA, whereas the electrophoretic mobility in agarose is inversely correlated with DNA size. Gel separation is mainly caused by a molecular sieving effect from agarose. Pore size depends on the gel concentration as well as the amount of cross-linking sites per unit weight, which also affects the melting and gelling points and the mechanical gel strength. Moreover, the ionic strength of buffers, voltage-current characteristics, and electro-osmotic coefficients of agarose also affect the electrophoretic behaviors of DNA. The simultaneous run of a set of known DNA size markers can negate the influences of the above-mentioned variation factors, and this makes it possible to calibrate DNA base pairs from electrophoretic mobility.

Pulsed-field gel electrophoresis (PFGE) [43-45] facilitates electrophoretic analyses of larger DNA. Since large DNA is very fragile to shear force, cells have to be embedded in an agarose plug prior to cell lysis [46]. The gel size is similar to the submarine macrogel electrophoresis; however, instead of constantly running the voltage in one direction, the voltage is periodically switched among multiple directions, and large DNA runs in a zigzag pattern through the agarose pores. Chromosomal DNA of many eukaryotes is too large to be separated even by PFGE; thus, DNA in agarose plugs are further digested with restriction endonucleases $[47,48]$. DNA size markers are also available in PFGE.

Single-cell micro-gel electrophoreses are quite different from the above two macro-methods: the cells are suspended in a thin agarose layer or disseminated on a glass slide and embedded with agarose. The crude lysate containing intact chromosomal DNA and various 
Citation: Kaneko S, Yoshida J, Ishikawa H, Takamatsu K (2013) Single-Nuclear DNA Instability Analyses by Means of Single-Cell Pulsed-Field Gel Electrophoresis - Technical Problems of the Comet Assay and Their Solutions for Quantitative Measurements. J Mol Biomark Diagn S5: 005. doi:10.4172/2155-9929.S5-005

Page 3 of 8

lengths of fragments are usually run without downsizing by restriction endonucleases. The electrophoretic images are usually observed by means of a fluorescent microscope. To achieve quantitative determination of DNA fragmentation in a single cell by means of microgel electrophoresis, it is essential to establish rigorous experimental conditions with some adequate comparative standards, such as DNA size markers and negative and positive controls.

\section{Single-Cell Pulsed-Field Gel Electrophoresis (SCPFGE)}

Human sperm with progressive motility was separated by means of Percoll density gradient centrifugation $[49,50]$ and the swim up method. The apparatus of SCPFGE is described in a previous report [27]. An aliquot of human sperm was adhered to a $7 \times 7 \mathrm{~mm}$ area of aminopropyl-silane-conjugated glass slides (MAS coat slide, Matsunami, Osaka, Japan) by centrifugal auto-smear (Cyto-Tek, SAKURA, Tokyo, Japan). The melted $0.33 \%$ agarose $(0.1 \mathrm{~mol} / \mathrm{L}$ sodium acetate $(\mathrm{pH} 4.7)$ with $0.05 \%$ Triton $\mathrm{X}-100$ ) was filtered with a $0.22 \mu \mathrm{m}$ pore membrane, and then aliquots $(540 \mu \mathrm{l})$ were mixed with $60 \mu \mathrm{l}$ of purified bovine $\operatorname{trypsin}(200 \mu \mathrm{g} / \mathrm{mL})$ at $40^{\circ} \mathrm{C}$. The sperm-adhered area of the glass slide was embedded in agarose $(2.5 \mathrm{~cm} \times 2.5 \mathrm{~cm}, 50 \mu \mathrm{m}$ thickness $)$ and chilled for $30 \mathrm{~min}$. The gel was incubated in the cell-lytic reagent (30 $\mathrm{mmol} / \mathrm{L}$ Tris- $\mathrm{HCl}, 8.2 \mathrm{mmol} / \mathrm{Lhexa}-\mathrm{metaphosphate} \mathrm{Na}, 0.05 \%$ Triton $\mathrm{X}-100,5.0 \mathrm{mmol} /$ Ldithiothreitol (DTT), $\mathrm{pH} 8.1$ ) at $37^{\circ} \mathrm{C}$ for $30 \mathrm{~min}$.

The SCPFGE apparatus was placed on a horizontal table, and the gel film on the glass slide was positioned at the cross-point of electric currents from two sets of electrodes arranged orthogonally. SPCFGE was performed at $1.5 \mathrm{~V} / \mathrm{cm}$ with $3.0 \mathrm{sec}$ switching intervals for $7 \mathrm{~min}$ in the electrophoretic buffer $(30 \mathrm{mmol} / \mathrm{L}$ Tris-acetate, $8.2 \mathrm{mmol} /$ Lhexa-metaphosphate $\mathrm{Na}, \mathrm{pH}$ 8.1). DNA in the gel was stained with diluted $\left(\times 10^{4}\right)$ Cyber-Gold (Molecular Probes, Oregon, USA) and was observed under an epifluorescent microscope (excitation: $495 \mathrm{~nm}$, emission: $537 \mathrm{~nm}$ )

\section{Importance of Trypsin Digestion for Single-Cell Micro- Gel Electrophoreses}

The comet assay [16-26] often uses cell lytic agents, including detergents to remove cell membranes, high salt (more than $2.0 \mathrm{~mol} /$ $\mathrm{LNaCl}$ ) to dissociate DNA-nucleoprotein complexes, and DTT to dissociate S-S bonds in nucleoproteins, and then it evaluates DNA damage from the amount of granular fragments that have migrated from the origin. Meanwhile, trypsin digestion of the embedded sperm altered the electrophoretic profiles drastically [27], and various sizes of DNA fibers migrated from the origin and were termed granular fragments, fibrous fragments, and long chain fibers, in increasing order of size. The granular fragment was observed as a small particle, the long chain fiber was elongated from the origin without interruption, and the fibrous fragment was recognized as a fiber that separated beyond the anterior end of the elongated long chain fibers.

The enzymatic properties of bovine pancreatic trypsin (EC.3.4.21.4) [51], with respect to substrate specificity and $\mathrm{pH}$ dependency, are thought to be optimum to digest embedded cells in agarose. Major nucleoproteins, histones [52], and protamine [53] are lysine- and arginine-rich basic proteins, and their amino- or guanidyl-residues are tightly coupled with $\mathrm{PO}_{4}$ in DNA through electrostatic bonding. The complex is further fixed to the nuclear membrane with the nuclear matrix [54-57]. Trypsin specifically cleaves the carboxy-side of lysine and arginine residues. In turn, proteinase $\mathrm{K}$ [58], which is widely employed to prepare cell lysates for DNA extraction, has chymotrypsin-like broad substrate specificity for aliphatic and aromatic residues of amino acids and acts in a wide $\mathrm{pH}$ range. In-gel digestion of the embedded cells needs to be initiated after completing gelation of agarose to avoid free diffusion of DNA fibers (as described later in Figure 1). Because the activity of trypsin is strictly dependent on $\mathrm{pH}$, this enzyme was kept inactive at $\mathrm{pH} 4.7$ until gelation was completed and was activated by immersing the gel into the cell-lytic reagents ( $\mathrm{pH}$ 8.1).Since commercially available preparations of trypsin are usually contaminated with pancreaticdeoxyribonucleases (DNases), trypsin is not popular for DNA studies. To remove autolyzed trypsin and DNases, twice-crystallized bovine pancreatic trypsin was further purified by affinity chromatography using lima bean trypsin inhibitorconjugated Sephacryl [59]. No DNase activity was found in the purified preparation (data not shown). The preparation was stored in $2.0 \%$ acetic acid ( $\mathrm{pH} 1.8$ ) to avoid autolysis.

Figure 1 suggests the significance of trypsin digestion for liberating DNA from various nuclear binding proteins. Both of the lytic agents caused swelling of heads (Figure 1A and 1B) and formed so-called "nuclear halos" [56]. The potential of $8.2 \mathrm{mmol} / \mathrm{L}$ polyvalent anions for dissociation of protamine-DNA was comparable to that of 2.0 $\mathrm{mol} / \mathrm{L}$ monovalent anion. Since the activity of trypsin was suppressed by $2.0 \mathrm{~mol} / \mathrm{L} \mathrm{NaCl}$, trypsin $(20 \mu \mathrm{g} / \mathrm{mL})$ was further added to the specimen in Figure 1B. The swollen heads disappeared, and long DNA fibers elongated freely (Figure 1C). These results suggested that the competitive dissociation by anionic agents produced nuclear halos, whereas the DNA was still fixed by the other DNA binding proteins, including the nuclear matrix, and trypsin degraded them.

The sperm in the purified fraction and the asthenozoospermic semen, in which more than $96 \%$ of the sperm were immotile, were embedded with $0.3 \%$ agarose and treated with the lytic agent $(8.2$ $\mathrm{mmol} / \mathrm{L}$ hexa-metaphosphate $\mathrm{Na}$, trypsin), respectively. The sperm
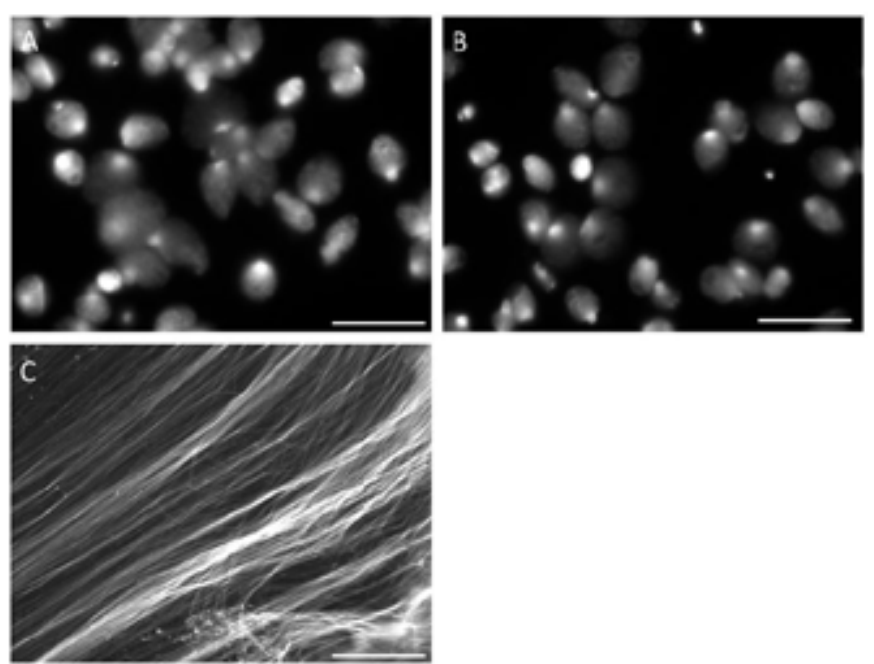

Figure 1: Significance of trypsin digestion for dissociating DNA fibers from nuclear DNA-binding components. The results shown in Figures 1-6 were obtained by using sperm prepared as described below using the ejaculate (vol. $=4.4 \mathrm{~mL}$, conc. $=76 \times 10^{6} \mathrm{sperm} / \mathrm{mL}$, motility $=59 \%$ ), the precipitate of the density-gradient $\left(200 \mu \mathrm{L}, 370 \times 10^{6} \mathrm{sperm} / \mathrm{mL}, 78 \%\right)$, and the swim-up fraction $\left(1.0 \mathrm{~mL}, 31 \times 10^{6} \mathrm{sperm} / \mathrm{mL}, 97 \%\right)$. Asthenozoospermic semen was defined by $3.8 \mathrm{~mL}, 46 \times 10^{6} \mathrm{sperm} / \mathrm{mL}$, and $3.6 \%$. The purified sperm with progressive motility were suspended in $30 \mathrm{mM}$ Tris- $\mathrm{HCl}, 0.05 \%$ Triton $X-100,5.0 \mathrm{mmol} / \mathrm{L}$ DTT, $\times 10^{4}$ diluted Cyber-Gold containing $2.0 \mathrm{~mol} / \mathrm{L} \mathrm{NaCl}(\mathrm{A})$ or $8.2 \mathrm{mmol} / \mathrm{L}$ hexa-metaphosphate $\mathrm{Na}(\mathrm{B})$, respectively. C: one-tenth volume of Trypsin $(20 \mu \mathrm{g} / \mathrm{mL})$ was subsequently added to the above specimen $\mathrm{A}$. The scale ba shown in the figures 1,2 and 5-7 represented $20 \mu \mathrm{m}$, and those in the figures 3 and 4 were $10 \mu \mathrm{m}$ 
Citation: Kaneko S, Yoshida J, Ishikawa H, Takamatsu K (2013) Single-Nuclear DNA Instability Analyses by Means of Single-Cell Pulsed-Field Gel Electrophoresis - Technical Problems of the Comet Assay and Their Solutions for Quantitative Measurements. J Mol Biomark Diagn S5: 005. doi:10.4172/2155-9929.S5-005

in the purified fraction showed a mass of tangled DNA fibers with a shaggy surface (Figure $2 \mathrm{~A}$ ). In contrast, the asthenozoospermic semen displayed heterogeneous profiles with numerous granular fragments dispersed through the porous gel without applying voltage (Figure 2B). These sperm were considered to be in the advanced stage of DNA fragmentation. Even after trypsin treatment, the digestive peptides still maintained ionic bonding ability to DNA in a low ionic strength solution. SCPFGE was performed in the presence of 8.2 $\mathrm{mmol} / \mathrm{L}$ hexa-metaphosphate Na. The results of SCPFGE suggested that the sperm in the purified fraction showed uniformly elongated fibers in several dozen quantities from each tangled mass (Figure 2C). They were either assigned to the group for which only the long chain fibers from the origin were observed (Figure 3A), or to the group for which fibrous fragments were observed beyond the anterior end of the elongated fibers (Figures 3B-3D). The number and size of fibrous fragments varied among the sperm. The electrophoretic images of the asthenozoospermic semen yielded heterogeneous stages of fragmentation (Figure 2D and Figures 4A-4C). The sum of profiles elucidated the process of DNA fragmentation: first, a few large fibrous fragments were cleaved (Figures 3B-3D) from the intact DNA fiber (Figure $2 \mathrm{C}$ and $3 \mathrm{~A}$ ), then the number and lengths of fibers elongated from the origin were decreased and shortened (Figure 4A) along with the increment of the cleavage sites, and finally, fibrous fragments were shredded to granular fragments (Figure $4 \mathrm{~B}$ ) and the origin was shrunk (Figure 4C). The degree of progression varied among the sperm and the frequency of appearance was altered among the specimens.

\section{Alkaline-based Single-Strand Break Assay}

The comet assay employs alkaline [16,17,21,24-26] conditions $(\mathrm{pH}>13)$ to dissociate hydrogen bonds that connect double strands. Alkaline-labile sites (ALS) [60] including AP sites [13,14] lead to DNA strand cleavage at high $\mathrm{pH}$, and alkaline-based SSB assays are at considerable risk of overestimation of SSB. The comet assay performed at $\mathrm{pH}$ 12.1-12.5 has been reported to detect SSB without the contamination of artifactual SSB from cleaved ALS; however, this modification has also been reported to reduce the sensitivity of that assay [61]. Miyamae et al. [62] also reported that reducing the $\mathrm{pH}$ to 12.1 during alkaline unwinding and electrophoresis appears to
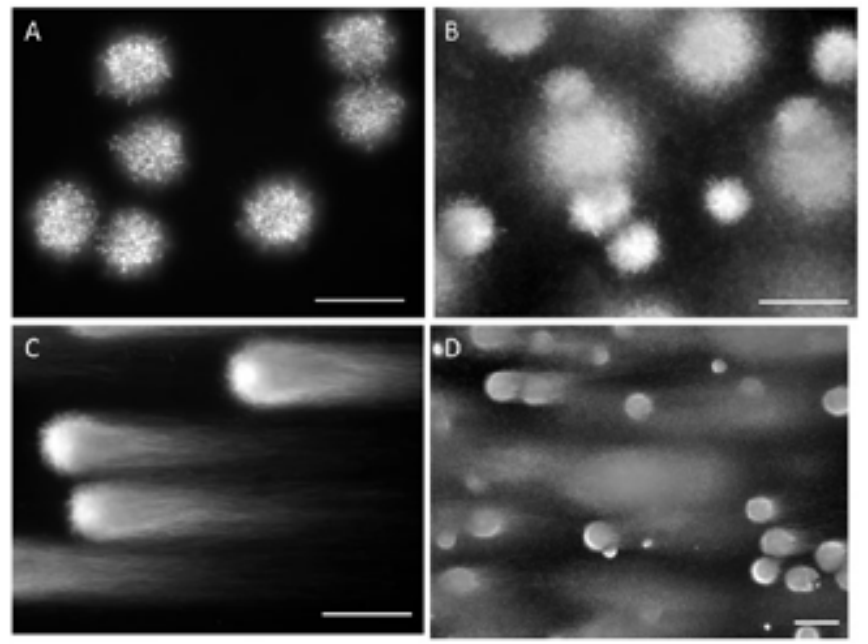

Figure 2: Effect of trypsin on the embedded sperm in the purified fraction and asthenozoospermic semen and their electrophoretic profiles. After cell lysis: A the purified sperm; B: the asthenozoospermic semen. SCPFGE images: C: the purified sperm; D: the asthenozoospermic semen.

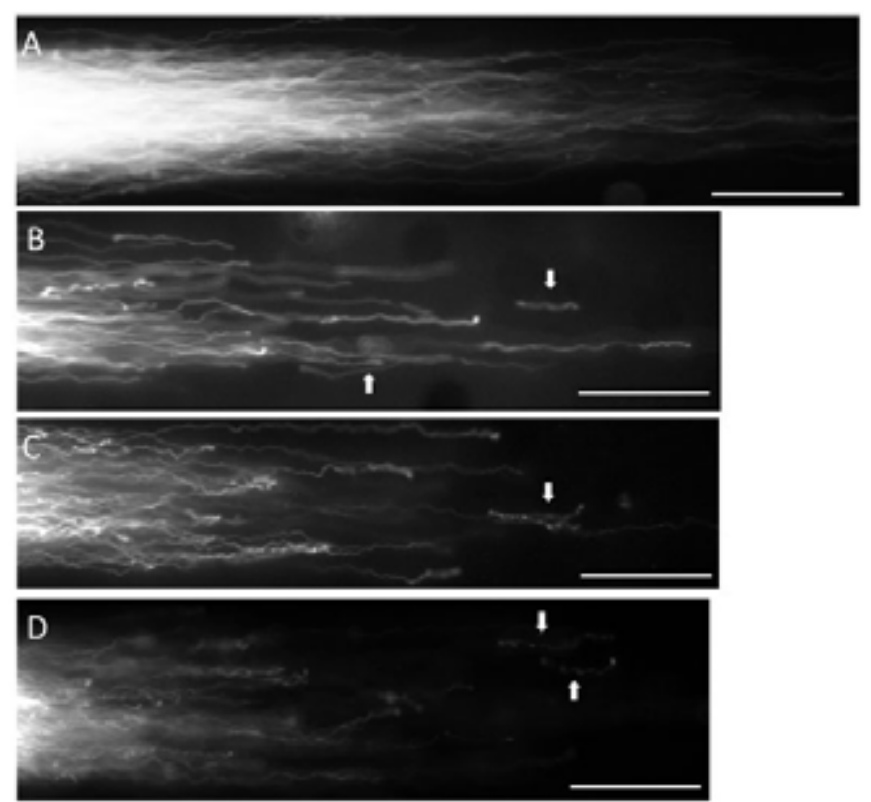

Figure 3: Typical profiles of intact DNA fibers and of fibrous DNA fragments in the purified sperm. A: intact image, B, C and D: initial stage of DNA fragmentation, arrows indicated number of fibrous fragments.

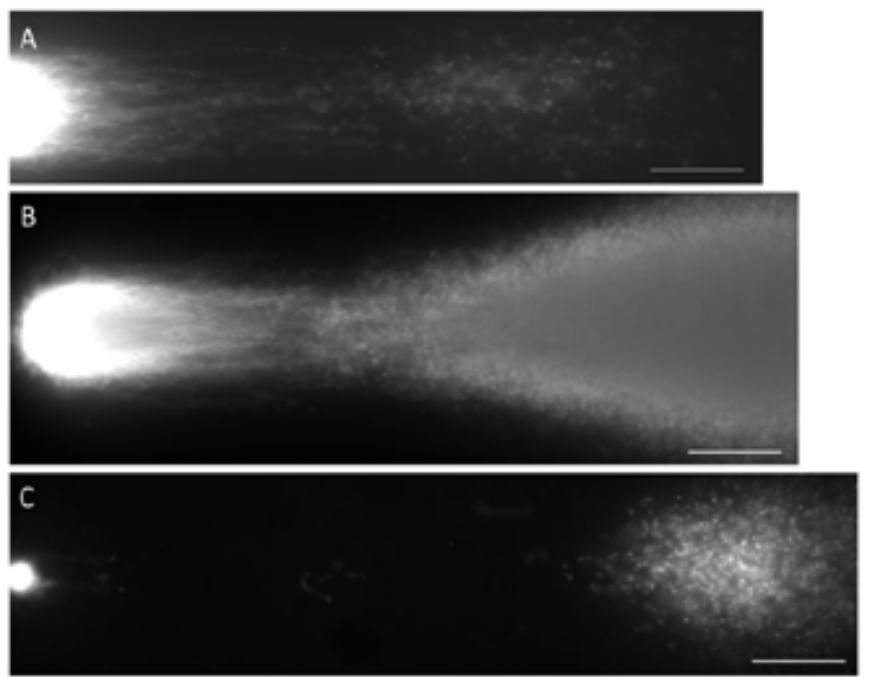

Figure 4: Fibrous and granular fragments shown in the asthenozoospermic semen. A: long chain fibers were elongated from the origin and small amount of granular fragments were found beyond the tips. B: along with the fragmentation were proceeded, amount of granular fragments were increased. C: finally fibrous fragments were disappeared and mass of the origin was shrunk.

eliminate the expression of ALS as SSB. Thus, the presence of increased migration at $\mathrm{pH} 13$, but its absence at $\mathrm{pH} 12.1$, indicates the specific induction of ALS. DNA denaturation and unwinding relies on the disruption of hydrogen bonds at high $\mathrm{pH}$, and it has been previously reported that AP sites are stable against alkaline cleavage at $\mathrm{pH}<12.6$ $[16,63]$. Luke et al. [64] highlighted the technical problems of the comet assay by means of macro-gel electrophoresis. DNA samples that involved chemically induced AP sites by heat/acid conditions [65] were stable at $\mathrm{pH} \leq 11.9$, but became increasingly cleaved at $\mathrm{pH} \geq 12.2$ in a dose-dependent manner. The nearly complete denaturation of DNA 
Citation: Kaneko S, Yoshida J, Ishikawa H, Takamatsu K (2013) Single-Nuclear DNA Instability Analyses by Means of Single-Cell Pulsed-Field Gel Electrophoresis - Technical Problems of the Comet Assay and Their Solutions for Quantitative Measurements. J Mol Biomark Diagn S5: 005. doi:10.4172/2155-9929.S5-005

required incubation of DNA at $\mathrm{pH} \geq 12.7$. This result suggested that the SSB assay that relies on an alkaline environment $(\mathrm{pH} \geq 12.2)$ for DNA denaturation may be inducing artifactual SSB through the cleavage of intact AP sites, resulting in an overestimation of SSB formation.

The above debate on the influence of $\mathrm{pH}$ to the first decimal place (around $\mathrm{pH}$ 12) requires that several fundamental chemical problems become highlighted: when measurements of high $\mathrm{pH}$ were taken with a glass electrode, the observed values were usually inaccurate to the first decimal place because these values were obtained using a faraway extrapolation of the calibration range between $\mathrm{pH}$ standards. Although $\mathrm{pH}$ glass electrodes respond very selectively to hydrogen ions, there is interference caused by alkaline ions, particularly sodium ions. This effect, called the alkaline error, increases with higher alkaline concentrations $(\mathrm{pH}>9)$ and increasing temperatures. The commercially available granular $\mathrm{NaOH}$ is deliquescent material and is present partly as $\mathrm{Na}_{2} \mathrm{CO}_{3}$ by adsorption of $\mathrm{CO}_{2}$ in air. When $\mathrm{NaOH}$ stock solution is prepared on a weight/volume basis, it has to be standardized by acid-base titration on each occasion according to the United States Pharmacopeia (USP) and the Association of Official Analytical Chemists (AOAC). This solution should also be sealed tightly in plastic bottles, and the working solution should be diluted just before use to avoid contamination of $\mathrm{CO}_{2}$ in air. Except in specialist of analytical chemistry, the validated $\mathrm{NaOH}$ reference solution for volumetric analyses should be employed and expressed as the concentration $(\mathrm{mmol} / \mathrm{L})$ instead of the observed values of $\mathrm{pH}$. The rate of hydrolytic reaction depends on not only the concentration of hydroxide ions, but also the temperature and reaction period. For example, electrophoresis in alkaline solutions $(\mathrm{pH}>13)$ causes a rise in temperature by Joule heating, and it also promotes hydrolysis.

The most fundamental problem of the alkaline comet assay is that the nuclear DNA binding components are tolerant to high $\mathrm{pH}$. Thus, the electrophoretic profiles of trypsin-treated sperm were entirely different from those without trypsin. The sperm with progressive motility were lysed with trypsin and treated with $10-30 \mathrm{mmol} / \mathrm{L} \mathrm{NaOH}$ at ambient temperature for $20 \mathrm{~min}$ prior to SCPFGE (Figure 5). The DNA fibers persisted in $10 \mathrm{mmol} / \mathrm{L} \mathrm{NaOH}$ (Figure $5 \mathrm{~A}$ ), whereas a small $10 \mathrm{mmol} / \mathrm{L}$ increase produced obvious changes in that the long chain fibers were slightly disrupted to granular fragments (Figure 5B). With $>20 \mathrm{mmol} / \mathrm{L}$ $\mathrm{NaOH}$, the amount of granular fragments increased (Figure 5C), and at $30 \mathrm{mmol} / \mathrm{L} \mathrm{NaOH}$, almost all the fibers were degraded to granules and the origin had shrunk (Figure 5D). Since the dose-response curve was found to be very steep, accuracy of the $\mathrm{NaOH}$ preparation was essential to ensure reproducibility.

The sperm in the purified fraction and the asthenozoospermic semen, respectively, were embedded with $0.3 \%$ agarose and treated by the lytic condition shown in Figure 1A $(2.0 \mathrm{~mol} / \mathrm{L} \mathrm{NaCl}$, without trypsin). When the purified sperm were lysed without trypsin, SCPFGE could not pull out the fiber (Figure 6A). In contrast, most of the sperm in the asthenozoospermic semen discharged granular fragments without the accompanying fibers (Figure 6B), whereas the amount was found to be smaller than those with trypsin digestion (Figure $2 \mathrm{~B}$ and $4 \mathrm{~B})$. The image in Figure 6B corresponds to the neutral comet assay without trypsin digestion. Then, the specimens shown in Figure 6A and $6 \mathrm{~B}$ were further treated with $20 \mathrm{mmol} / \mathrm{L} \mathrm{NaOH}$ for $20 \mathrm{~min}$. Small amounts of granular fragments were retrieved from the purified sperm (Figure 6C). In the asthenozoospermic semen, the amount of fragments (Figure 6D) was increased from Figure 6B, but was less than that in Figure 2D. The electrophoretic profiles in Figure 6D were similar to those in the alkaline comet assay.
These facts suggested that at least some of the nuclear DNA binding components were tolerant to high salt and high alkalinity, but were degraded by trypsin digestion. Thus, a lack of trypsin digestion caused false negative results in both procedures: most DNA fibers were still fixed with the components, and the comet tail did not reflect the total amount of granular fragments, but rather those fragments released from the components.

The results shown in Figure 5 and 6 merely elucidated that the granular DNA fragments were neo-generated by high $\mathrm{pH}$, but the mechanism of such a result remained unclear; that is, it was unknown if it was due to dissociation of hydrogen bonds, strand break through beta- and/or delta- eliminations [15] of ALS, artifactual DSB, or some other combination of actions. It remains obscure whether commonly used, highly concentrated $100-300 \mathrm{mmol} / \mathrm{L} \mathrm{NaOH}$ in the alkaline comet assay included artifactual DSB or not. When fragments are
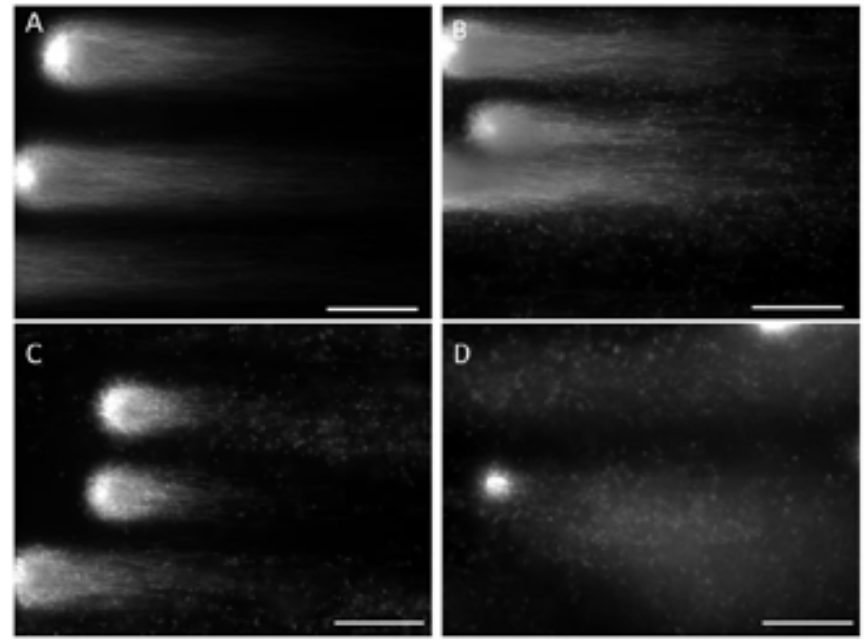

Figure 5: Effect of concentrations of $\mathrm{NaOH}$ on purified sperm lysed with trypsin. A: 10, B: 15, C: $20, \mathrm{D}: 30 \mathrm{mmol} / \mathrm{L} \mathrm{NaOH}$. The reagents were prepared from $100 \mathrm{mmol} / \mathrm{L} \mathrm{NaOHreference} \mathrm{solution} \mathrm{(Factor}=1.001$ at $20^{\circ} \mathrm{C}$ ).
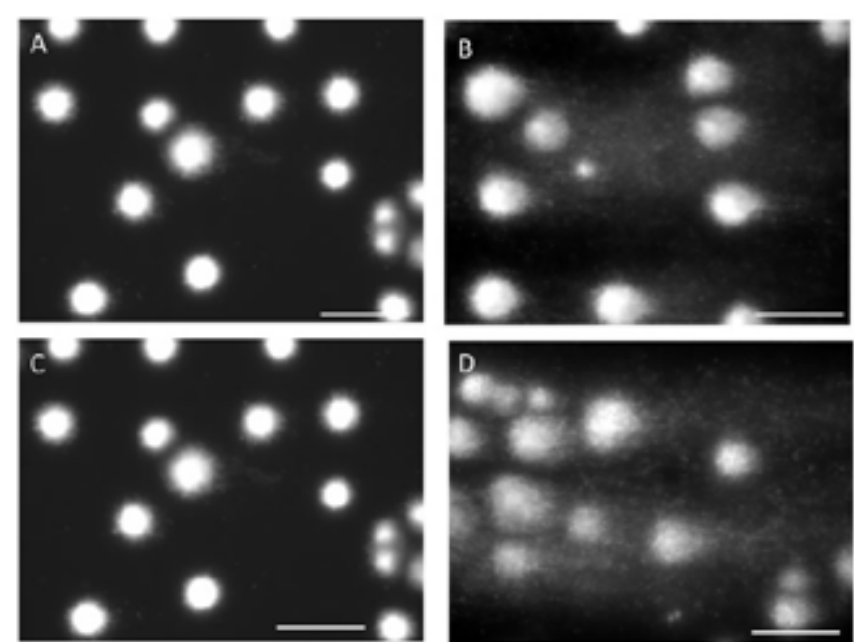

Figure 6: Effects of alkalinity on the embedded sperm in the purified fraction and the asthenozoospermic semen that were lysed with $2.0 \mathrm{~mol} / \mathrm{L} \mathrm{NaCl}$ without trypsin. The electrophoretic profiles for the purified sperm $(A, C)$ and asthenozoospermic semen $(B, D)$, without $(A, B)$ and with $\mathrm{NaOH}$ treatment $(C, D)$. 
Citation: Kaneko S, Yoshida J, Ishikawa H, Takamatsu K (2013) Single-Nuclear DNA Instability Analyses by Means of Single-Cell Pulsed-Field Gel Electrophoresis - Technical Problems of the Comet Assay and Their Solutions for Quantitative Measurements. J Mol Biomark Diagn S5: 005. doi:10.4172/2155-9929.S5-005

visualized by intercalation fluorescent dyes, their binding specificities are not absolutely distinguishable between single- and double-strand DNA. The manner of cleavages should be identified with more specific methods such as the DNA breakage detection-fluorescence in situ hybridization (DBD-FISH) techniques [66,67], terminal transferased UTP nick end labeling (TUNEL) assays, and anti-single strand DNA monoclonal antibodies [68].

\section{Diagnostic Significance of the Comet Assay and SCPFGE in ART}

Through the past decade, clinicians and patients have taken notice of the significance of accumulated DNA damage in human sperm and have linked such processes to male infertility and congenital anomalies. The neutral and alkaline comet assays have been the major tools for determination of nonspecific DNA damage, and approximately 7,000 articles were hit on "PubMed" by keyword searching of "comet assay".

As shown in Figure 2C and 3, almost all the progressively motile sperm in the purified fraction consisted of long chain fibers. In contrast, most of the immotile sperm in asthenozoospermic semen were found to be in the advanced stages with granular fragments (Figure 2D and 4). These sperm could be excluded during the in vitro processing to select for progressively motile sperm. These results suggested that the sperm with granular fragment might be immotile. As shown in Figure 3 , SCPFGE detected a few large fibrous fragments being derived from whole DNA, and our previous report [27] revealed that at least a portion of motile sperm in the purified fractions had already entered in the early stage of DNA fragmentation. Motility, therefore, could not offer complete assurance in terms of DSB. The neutral and alkaline comet assays could not detect such early stages of DNA fragmentation in motile sperm (Figure 6A and 6C), and, as emphasized above, some inadequate experimental conditions cause false negatives in both procedures. Thus, the optimum conditions must be reconsidered in order to achieve quantitative measurements. SCPFGE is likely to serve as a fundamental step in preoperative differential diagnosis to determine the competence of the sperm population provided for injection, and is likely to play an important role in ensuring the safety of clinical ICSI.

\section{Quality Control of SCPFGE and its Future Prospects}

The electrophoretic behaviors of DNA fibers are mainly influenced by quality and concentration of agarose, binding of agarose to solid phase, enzymatic digestion of cells, settings for pulsed-field electrophoresis, it is essential to determine the optimum combination of these factors to establish the standard protocol for SCPFGE. Adequate comparative standards, such as negative and positive controls of DSB and DNA size markers, are also desired for quality control of SCPFGE. We would like to make tentative suggestions that the progressively motile sperm in the purified fraction (Figure $2 \mathrm{C}$ and 3 ) and the immotile sperm in asthenozoospermic semen (Figure 2D and 4 ) are suitable as cell models for positive and negative controls of DSB. The prokaryotic whole DNA may be a candidate of the size markers for micro-gel electrophoresis, as shown in Figure 7. A DNA fiber (4.6 M base pairs) from Escherichia coli [69] were run in SCPFGE, and was unfortunately entangled in the insoluble material and could not be migrated as a stretching line.

This review mainly focused on the detection of nonspecific DNA lesions in the strands, and SCPFGE may offer another prospect as a visualization tool for DNA fibers derived from a single cell. FISH [7] provides a mapping resolution of 1 to $3 \mathrm{M}$ base pairs for metaphase chromosomes and a resolution of $50 \mathrm{~kb}$ and ranges of 1-2 $\mathrm{M}$ base

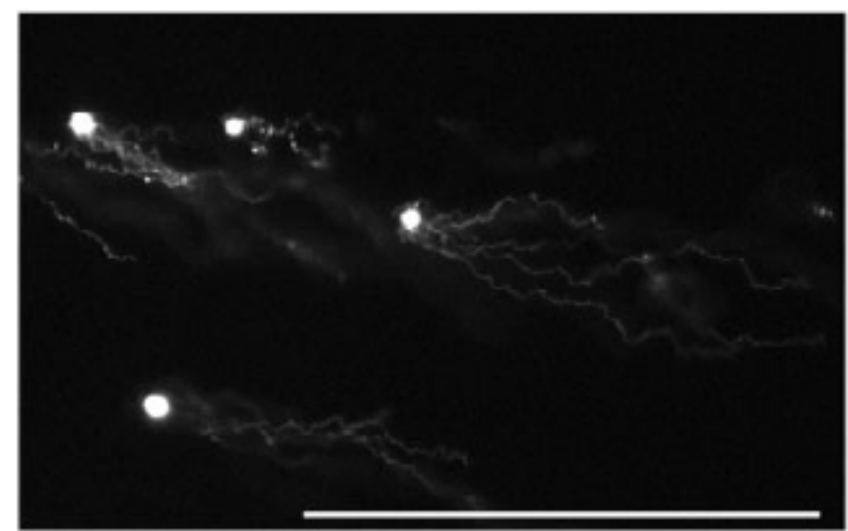

Figure 7: SCPFGE profile of $E$. coll.

pairs for interphase nuclei. This better resolution is attributed to the higher degree of chromatin decondensation. Hence, FISH for fully naked DNA fibers, the so-called "DNA fiber FISH", shows the highest resolution range of at least $1-400 \mathrm{~K}$ base pairs [70]. It provides a tool for restriction mapping because it permits very accurate gap and overlap sizing. Also, it provides the means to generate "color bar codes" for disease regions, which can be used to inspect patient DNA for suspected gene rearrangements. The technical difficulties of DNA fiber FISH include defining how to make long chain naked DNA, stretch DNA fibers, and fixation on the solid phase [71]. The digestion of embedded human sperm with trypsin dissociated DNA fibers from nuclear DNA binding components and subsequent SCPFGE elongated the bundle of DNA fibers derived from a single cell [27]. Prior to DNA fiber FISH, the eligibility of specimens can be evaluated by SCPFGE, the cells with DNA fragments should be eliminated from the test object.

\section{References}

1. Kaneko S, Takamatsu K (2012) Cell Handling and culture under controlled oxygen concentration: Biomedical Tissue Culture, INTECH, Croatia, edited by Luca Ceccherini-Nelli and Barbara Matteoli, ISBN 978-953-51-0788-0.

2. Kalisky T, Quake SR (2011) Single-cell genomics. Nat Methods 8: 311-314.

3. Wang J, Fan HC, Behr B, Quake SR (2012) Genome-wide single-cell analysis of recombination activity and de novo mutation rates in human sperm. Cell 150: 402-412.

4. d'Hennezel E, Yurchenko E, Sgouroudis E, Hay V, Piccirillo CA, et al. (2011) Single-cell analysis of the human $T$ regulatory population uncovers functional heterogeneity and instability within FOXP3 ${ }^{+}$cells. J Immunol 186: 6788-6797.

5. Varadarajan N, Julg B, Yamanaka YJ, Chen H, Ogunniyi AO, et al. (2011) A high-throughput single-cell analysis of human $\mathrm{CD} 8^{+} \mathrm{T}$ cell functions reveals discordance for cytokine secretion and cytolysis. J Clin Invest 121: 4322-4331.

6. White AK, VanInsberghe M, Petriv OI, Hamidi M, Sikorski D, et al. (2011) Highthroughput microfluidic single-cell RT-qPCR. Proc Natl Acad Sci U S A 108 : 13999-14004.

7. Trask BJ (1991) Fluorescence in situ hybridization: applications in cytogenetics and gene mapping. Trends Genet 7: 149-154

8. Zong C, Lu S, Chapman AR, Xie XS (2012) Genome-wide detection of singlenucleotide and copy-number variations of a single human cell. Science 338 1622-1626.

9. Arends MJ, R. Morris G, Wyllie AH (1990) Apoptosis. The role of the endonuclease. Am J Pathol 136: 593-608.

10. Chun SY, Eisenhauer KM, Minami S, Billig H, Perlas E, et al. (1996) Hormona regulation of apoptosis in early antral follicles: follicle-stimulating hormone as a major survival factor. Endocrinology 137: 1447-1456.

11. Cain K (2003) Chemical-induced apoptosis: Formation of the apaf-1 apoptosome. Drug Metab Rev 35: 337-363. 
Citation: Kaneko S, Yoshida J, Ishikawa H, Takamatsu K (2013) Single-Nuclear DNA Instability Analyses by Means of Single-Cell Pulsed-Field Gel Electrophoresis - Technical Problems of the Comet Assay and Their Solutions for Quantitative Measurements. J Mol Biomark Diagn S5: 005. doi:10.4172/2155-9929.S5-005

12. Fromme JC, Verdine GL (2004) Base excision repair. Adv Protein Chem 69: $1-41$.

13. David-Cordonnier MH, Cunniffe SM, Hickson ID, O'Neill P (2002) Efficiency of incision of an AP site within clustered DNA damage by the major human AP endonuclease. Biochemistry 41: 634-664.

14. Wiederhold L, Leppard JB, Kedar P, Karimi-Busheri F, Rasouli-Nia A, et al. (2004) AP endonuclease-independent DNA base excision repair in human cells. Mol Cell 15: 209-220.

15. Lhomme J, Constant JF, Demeunynck M. (1999) Abasic DNA structure, reactivity, and recognition. Biopolymers 52: 65-83.

16. Tice RR, Agurell E, Anderson D. Burlinson B, Hartmann A, et al. (2000) Single cell gel/comet assay: guidelines for in vitro and in vivo genetic toxicology testing. Environ Mol Mutagen 35: 206 -222.

17. Hartmann A, Agurell E, Beevers C, Brendler-Schwaab S, Burlinson B, et al (2003) Recommendations for conducting the in vivo alkaline comet assay. 4th International Comet Assay Workshop. Mutagenesis 18: 45-51.

18. Olive PL, Banáth JP (2006) The comet assay: a method to measure DNA damage in individual cells. Nature Protoc 1: 23 - 29.

19. Wojewódzka M, Buraczewska I, Kruszewski M (2002) A modified neutral comet assay: elimination of lysis at high temperature and validation of the assay with anti-single-stranded DNA antibody. Mutat Res 518: 9-20.

20. Morris ID, llott S, Dixon L, Brison DR (2002) The spectrum of DNA damage in human sperm assessed by single cell gel electrophoresis (Comet assay) and its relationship to fertilization and embryo development. Hum Reprod 17 990-998.

21. Fairbairn DW, Olive PL, O'Neill KL (1995) The comet assay: a comprehensive review. Mutat Res 339: 37-59.

22. Tice RR, Strauss GH (1995) The single cell gel electrophoresis/comet assay: a potential tool for detecting radiation-induced DNA damage in humans. Stem Cells 1: 207-214.

23. Speit G, Hartmann A (2006) The comet assay: a sensitive genotoxicity test for the detection of DNA damage and repair. Methods Mol Biol 314: 275-286.

24. McKelvey-Martin VJ, Green MH, Schmezer P, Pool-Zobel BL, De Méo MP, et al. (1993) The single cell gel electrophoresis assay (comet assay): a European review. Mutat Res 288: 47-63.

25. Klaude M, Eriksson S, Nygren J, Ahnström G (1996) The comet assay: mechanisms and technical considerations. Mutat Res 363: 89-96.

26. Moller $P$ (2006) The alkaline comet assay: towards validation in biomonitoring of DNA damaging exposures. Basic Clin Pharmacol Toxicol 98: 336-345.

27. Kaneko S, Yoshida J, Ishikawa H, Takamatsu K (2012) Single-cell pulsed-field gel electrophoresis to detect the early stage of DNA fragmentation in human sperm nuclei. PLoS One 7: e42257.

28. Olsen AK, Lindeman B, Wiger R, Duale N, Brunborg G (2005) How do male germ cells handle DNA damage? Toxicol Appl Pharmacol 207: 521-531.

29. Brandriff B, Pedersen RA (1981) Repair of the ultraviolet-irradiated male genome in fertilized mouse eggs. Science 211: 1431-1433.

30. Ashwood-Smith MJ, Edwards RG (1996) DNA repair by oocytes. Mol Hum Reprod 2: 46-51.

31. Jaroudi S, SenGupta S (2007) DNA repair in mammalian embryos. Mutat Res 635: 53-77.

32. Derijck A, van der Heijden G, Giele M, Philippens M, de Boer P (2008) DNA double-strand break repair in parental chromatin of mouse zygotes, the first cell cycle as an origin of de novo mutation. Hum Mol Genet 17: 1922-1937.

33. Yuan J, Narayanan L, Rockwell S, Glazer PM (2000) Diminished DNA repair and elevated mutagenesis in mammalian cells exposed to hypoxia and low $\mathrm{pH}$ Cancer Res 60: 4372-4376.

34. Zheng P, Schramm RD, Latham KE (2005) Developmental regulation and in vitro culture effects on expression of DNA repair and cell cycle checkpoin control genes in rhesus monkey oocytes and embryos. Biol Reprod 72: 13591369.

35. Marchetti F, Essers J, Kanaar R, Wyrobek AJ (2007) Disruption of materna DNA repair increases sperm-derived chromosomal aberrations. Proc Natl Acad Sci U S A 104: 17725-17729.
36. Ludwig M, Katalinic A (2002) Malformation rate in fetuses and children conceived after ICSI: results of a prospective cohort study. Reprod Biomed Online 5: 171-178.

37. Hindryckx A, Peeraer K, Debrock S, Legius E, de Zegher F, et al. (2010) Has the prevalence of congenital abnormalities after intracytoplasmic sperm injection increased? The Leuven data 1994-2000 and a review of the literature. Gynecol Obstet Invest 70: 11-22.

38. Davies MJ, Moore VM, Willson KJ, Van Essen P, Priest K, et al. (2012) Reproductive technologies and the risk of birth defects. N Engl J Med 366 : 1803-1813.

39. Khanna KK, Jackson SP (2001) DNA double-strand breaks: signaling, repai and the cancer connection. Nat Genet 27: 247-254.

40. Hefferin ML, Tomkinson AE (2005) Mechanism of DNA double-strand break repair by non-homologous end joining. DNA Repair (Amst) 4: 639-648.

41. Voytas D (2001) Agarose gel electrophoresis. Curr Protoc Immunol Chapter 10: Unit 10.

42. Holmes DL, Stellwagen NC (1990) The electric field dependence of DNA mobilities in agarose gels: a reinvestigation. Electrophoresis 11: 5-15.

43. Schwartz DC, Cantor CR (1984) Separation of yeast chromosome-sized DNAs by pulsed field gradient gel electrophoresis. Cell 37: 67-75

44. Carle GF, Frank M, Olson MV (1986) Electrophoretic separations of large DNA molecules by periodic inversion of the electric field. Science 232: $65-68$

45. Ziegler A, Geiger KH, Ragoussis J, Szalay G (1987) A new electrophoretic apparatus for separating very large DNA molecules. J Clin Chem Clin Biochem 25: $578-579$

46. Sambrook J, Russell DW (2006) Preparation of DNA for Pulsed-field Ge Electrophoresis: Isolation of DNA from Mammalian Cells and Tissues. CSH Protoc 2006.

47. Nasonova ES (2008) [Pulsed field gel electrophoresis: theory, instruments and applications]. Tsitologiia 50: 927-935.

48. Sambrook J, Russell DW (2006) Restriction endonuclease digestion of DNA in agarose plugs. CSH Protoc 2006

49. Kaneko S, Oshio S, Kobanawa K, Kobayashi T, Mohri H, et al. (1986) Purification of human sperm by a discontinuous Percoll density gradient with an innercolumn. Biol Reprod 35: 1059-1063

50. Kaneko S, Sato H, Kobanawa K, Oshio S, Kobayashi T, et al. (1987) Continuous-step density gradient centrifugation for the selective concentration of progressively motile sperm for insemination with husband's semen. Arch Androl 19: 75-84

51. Rawlings ND, Barrett AJ (1994) "Families of serine peptidases". Meth Enzymo 244: 19-61. doi:10.1016/0076-6879(94)44004-2.

52. Richmond TJ, Davey CA (2003) The structure of DNA in the nucleosome core. Nature 423: 145-150

53. Balhorn R (2007) The protamine family of sperm nuclear proteins. Genome Biol 8: 227.

54. Kramer JA, Krawetz SA (1996) Nuclear matrix interactions within the sperm genome. J Biol Chem 271: 11619-11622.

55. Nickerson J (2001) Experimental observations of a nuclear matrix. J Cell Sci 114: 463-474.

56. Shaman JA, Yamauchi Y, Ward WS (2007) Function of the sperm nuclea matrix. Arch Androl 53: 135-140.

57. He DC, Nickerson JA, Penman S (1990) Core filaments of the nuclear matrix J Cell Biol 110: 569-580.

58. Ebeling W, Hennrich N, Klockow M, Metz H, Orth HD, et al. (1974) Proteinase $\mathrm{K}$ from Tritirachium album Limber. Eur J Biochem 47: 91-97.

59. Kobayashi T, Matsuda Y, Park JY, Hara I, Kaneko S, et al. (1992) Trypsinlike arginine amidases including plasminogen and plasmin in human seminal plasma by affinity adsorption and elution. Arch Androl 28: 165-170.

60. Schutte HH, van der Schans GP, Lohman PH (1988) Comparison of induction and repair of adducts and of alkali-labile sites in human lymphocytes and granulocytes after exposure to ethylating agents. Mutat Res 194: 23-37.

61. Speit G, Schütz P, Bonzheim I, Trenz K, Hoffmann H (2004) Sensitivity of the 
Citation: Kaneko S, Yoshida J, Ishikawa H, Takamatsu K (2013) Single-Nuclear DNA Instability Analyses by Means of Single-Cell Pulsed-Field Gel Electrophoresis - Technical Problems of the Comet Assay and Their Solutions for Quantitative Measurements. J Mol Biomark Diagn S5: 005. doi:10.4172/2155-9929.S5-005

FPG protein towards alkylation damage in the comet assay. Toxicol Lett 146: $151-158$.

62. Miyamae Y, Iwasaki K, Kinae N, Tsuda S, Murakami M, et al. (1997) Detection of DNA lesions induced by chemical mutagens using the single-cell gel electrophoresis (comet) assay. 2. Relationship between DNA migration and alkaline condition. Mutat Res 393: 107-113.

63. Chlebowicz E, Jachymczyk WJ (1979) Repair of MMS-induced DNA doublestrand breaks in haploid cells of Saccharomyces cerevisiae, which requires the presence of a duplicate genome. Mol Gen Genet 167: 279-286.

64. Luke AM, Chastain PD, Pachkowski BF, Afonin V, Takeda S, et al. (2010) Accumulation of true single strand breaks and AP sites in base excision repair deficient cells. Mutat Res 694: 65-71.

65. Nakamura J, Walker VE, Upton PB, Chiang SY, Kow YW, et al. (1998) Highly sensitive apurinic/apyrimidinic site assay can detect spontaneous and chemically induced depurination under physiological conditions. Cancer Res 58: $222-225$.
66. Fernández JL, Goyanes VJ, Ramiro-Díaz J, Gosálvez J (1998) Application of FISH for in situ detection and quantification of DNA breakage. Cytogenet Cell Genet 82: 251-256.

67. Fernández JL, Gosálvez J (2002) Application of FISH to detect DNA damage. DNA breakage detection-FISH (DBD-FISH). Methods Mol Biol 203: 203-216.

68. Frankfurt OS, Robb JA, Sugarbaker EV, Villa L (1996) Monoclonal antibody to single-stranded DNA is a specific and sensitive cellular marker of apoptosis. Exp Cell Res 226: 387-397.

69. Blattner FR, Plunkett G 3rd, Bloch CA, Perna NT, Burland V, et al. (1997) The complete genome sequence of Escherichia coli K-12. Science 277: 1453-1462.

70. Raap AK, Florijn RJ, Blonden LAJ, Wiegant J, Vaandrager JW, et al. (1996) Fiber FISH as a DNA Mapping Tool Methods 9: 67-73.

71. Ersfeld K (2004) Fiber-FISH: fluorescence in situ hybridization on stretched DNA. Methods Mol Biol 270: 395-402.
This article was originally published in a special issue, DNA Diagnosis handled by Editor(s). Dr. George J. Netto, Johns Hopkins University, USA;

Dr. Yang Yongliang, Harvard University, USA; Dr. Shahrokh Francois Shariat,

Cornell University, USA 